\title{
IMPLEMENTASI ETNOMATEMATIKA DALAM PEMBELAJARAN MATEMATIKA PADA JENJANG PENDIDIKAN SEKOLAH DASAR
}

\author{
Fatimah S. Sirate \\ Sekolah Tinggi Keguruan dan Ilmu Pendidikan YPUP \\ Jl. Andi Tonro Makassar \\ Emai: fatimahsirate@yahoo.com
}

\begin{abstract}
Abstrak:
Artikel ini mengkaji implementasi etnomatematika dalam pembelajaran matematika pada jenjang pendidikan sekolah dasar. Tujuan tulisan ini adalah untuk mendeskripsikan pelaksanaan proses pembelajaran matematika yang materinya diangkat dari nilai-nilai budaya lokal yang bersifat matematika atau disebut dengan etnomatematika. Jenis penelitian ini adalah penelitian kualitatif dengan pendekatan fenomenologis bertujuan untuk mendapatkan informasi selengkap mungkin mengenai implementasi etnomatematika dalam pembelajaran matematika pada tingkat sekolah dasar. Metode pengumpulan data menggunakan teknik observasi, wawancara, dan dokumentasi, kemudian dianalisis dengan reduksi data, sajian data, verifikasi, dan penyimpulan. Hasil penelitian menunjukkan bahwa dalam proses pembelajaran matematika, guru kelas IV, V, VI telah memanfaatkan etnomatematika dalam pembelajaran matematika, walaupun dalam menyusun rencana pembelajaran sama sekali tidak terlihat etnomatematika termuat di rencana pembelajaran yang dibuat. Penerapan etnomatematika sebagai sarana untuk memotivasi, menstimulasi siswa, dapat mengatasi kejenuhan dan memberikan nuansa baru pada pembelajaran matematika.
\end{abstract}

\begin{abstract}
:
This article examines the implementation of ethnomathematics in mathematics instruction at elementary school level. The purpose of this study is to describe the implementation process of mathematics instruction that the instructional materials are taken from the local cultural values that is called ethnomathematics. This research is a qualitative study with a phenomenological approach that aims at obtaining information regarding the implementation of ethnomathematics. The methods of data collection used in this study are observation, interviews, and documentation. Methods of analyzing data include data reduction, presentation, verification, and conclution. The result shows that mathematics teachers at the IV, $\mathrm{V}$, and VI grade applied ethnomathematics in learning mathematics, although the lesson plan did not contain the ethnomathematics contents. Application of ethnomathematics was used as a means to motivate and stimulate the students to overcome boredom and give a new situation to the learning of mathematics.
\end{abstract}

Kata kunci:

Etnomatematika, pembelajaran, integrasi budaya

GAGASAN memasukkan etnomatematika dalam kurikulum sekolah bukanlah hal baru. Dengan memasukkan etnomatematika dalam kurikulum sekolah akan memberikan nuansa baru dalam pengajaran matematika di sekolah dengan pertimbangan bahwa bangsa Indonesia terdiri atas berbagai macam suku dan budaya, dan setiap 
suku memiliki cara tersendiri dalam menyelesaikan masalah yang dihadapi, seperti halnya suku Tolaki yang ada di Sulawesi Tenggara. Pertimbangan lain bahwa matematika yang diperoleh di sekolah tidak cocok dengan cara hidup masyarakat setempat, sehingga matematika sulit dipahami oleh siswa karena ada dua skema yang diperoleh yaitu skema yang diperoleh di lingkungan dan skema yang diperoleh di sekolah.

Dua hal tersebut diduga sebagai penyebab sulitnya siswa mempelajari matematika. Oleh sebab itu dalam kurikulum matematika modern terdapat dua cara mengajarkan matematika. Pertama, matematika informal yang diajarkan sejak Taman Kanak-kanak sampai Sekolah Dasar kelas 3. Matematika ini berisi matematika yang sering ditemukan siswa pada lingkungan mereka yang diterapkan oleh masyarakat setempat. Matematika ini dapat dikatakan sebagai matematika yang mengandung muatan lokal. Kedua, matematika formal diajarkan sejak kelas 4 Sekolah Dasar ke atas. Matematika jenis ini berisi matematika yang tidak terlalu menekankan muatan lokal, tetapi menuju kepada matematika tingkat lanjut. ${ }^{1}$

Matematika bukanlah domain pengetahuan formal yang universal, tetapi merupakan kumpulan representasi dan prosedur simbolik yang terkonstruksi secara kultural dalam kelompok masyarakat tertentu. ${ }^{2}$ Ketika pemikiran peserta didik berkembang, mereka menggabungkan representasi dan prosedur ke dalam sistem kognitif mereka. Suatu proses telah terjadi dalam konteks aktivitas yang terkontruksi secara sosial. Keterampilan matematika yang dipelajari oleh peserta didik di sekolah tidak terkontruksi secara logis dan berdasarkan pada struktur kognitif abstrak, melainkan sebagai kombinasi pengetahuan dan keterampilan yang telah diperoleh sebelumnya serta sebagai masukan (budaya) baru dimana aktivitas yang melibatkan bilangan, pola-pola geometri, hitungan dan sebagainya dianggap sebagai aplikasi pengetahuan matematika.

Piaget menggunakan istilah skemata untuk konsepsi awal. Apabila skemata berkembang sebagai akibat dari penyesuaian terhadap perubahan, maka terjadi adaptasi. Skemata atau struktur kognitif yang dimiliki seseorang terjadi karena proses asimilasi dan akomodasi. mengungkapkan bahwa asimilasi adalah proses mendapatkan informasi dan pengalaman baru yang langsung menyatu dengan struktur mental (skemata) yang telah dimiliki seseorang. Sedangkan akomodasi adalah proses menstrukturkan kembali mental sebagai akibat adanya informasi dan pengalaman baru. ${ }^{3}$ Jadi belajar tidak hanya menerima informasi dan pengalaman baru, tetapi juga penstrukturan kembali informasi dan pengalaman lamanya untuk mengakomodasikan informasi dan pengalaman baru. Informasi baru terkait dengan informasi lain yang diharapkan menyatu dengan skemata siswa sehingga terjadi pembentukan pengetahuan.

Beberapa istilah yang digunakan oleh Pinxten yang merujuk matematika yang tidak dikembangkan secara formal di sekolah. Seperti ungkapan "m", matematika informal Gerdes, matematika di luar sekolah Nunes, matematika budaya Shirley, mate- 
matika yang mengandung muatan lokal. Sedang Tip dan Resdiesel, dkk atau D' Ambrosio dan Bishop, menggunakan istilah ethnomathematics. ${ }^{4}$

Semua peserta didik mengakui bahwa matematika itu penting, namun sebagian dari mereka sering mengalami kesulitan dalam mempelajarinya. Persoalan ini muncul karena adanya konflik budaya, ketidaksesuaian tradisi budaya yang mereka temukan di luar sekolah yaitu di rumah dan di masyarakat dengan apa yang mereka temukan di sekolah. Pengajaran matematika bagi setiap orang seharusnya disesuaikan dengan budayanya. ${ }^{5}$ Untuk itu diperlukan suatu yang dapat menghubungkan antara matematika di luar sekolah dengan matematika di dalam sekolah. Salah satu cara dengan memanfaatkan pendekatan ethnomathematics sebagai awal dari pengajaran matematika formal yang sesuai dengan tingkat perkembangan siswa yang berada pada tahapan operasional konkret. ${ }^{6}$ Hal yang sama dikemukakan bahwa kehadiran matematika yang bernuansa budaya akan memberikan konstribusi yang besar terhadap matematika sekolah, karena sekolah merupakan institusi sosial yang berbeda dengan yang lain sehingga memungkinkan terjadinya sosialisasi antara beberapa budaya. ${ }^{7}$ Dikatakan pula bahwa semua pendidikan matematika formal adalah suatu proses interaksi budaya dan setiap siswa mengalami berbagai konflik budaya dalam proses tersebut. 8

Menurut pandangan kaum psikologi perkembangan, untuk berhasil mempelajari matematika sebagai suatu objek, maka subjek harus sudah mempunyai akses terhadap konsep tersebut sebagai alat. ${ }^{9}$ Peserta didik sebagai subjek telah memiliki pengetahuan awal yang diperoleh dari lingkungan sosial budayanya. Oleh karena itu, perbedaan budaya menyebabkan terjadi perbedaan cara pandang yang membawa dampak pada perbedaan pengetahuan.$^{10}$

Salah satu unsur terpenting dalam pembahasan mengenai pendidikan dalam hubungannya dengan budaya adalah integrasi conten yang dipahami sebagai integrasi pendidikan multikultural dalam kurikulum. ${ }^{11}$ Isi kurikulum mencakup masalah bagaimana mengurangi berbagai prasangka di dalam tingkah laku racial dari etniketnik tertentu dan di dalam materi apa prasangka-prasangka tersebut dapat dikemukakan. Dalam hal ini, diperlukan studi menyangkut jenis-jenis kebudayaan dari kelompok-kelompok etnis. Demikian pula pendidikan antar kelompok diperlukan sehingga setiap kelompok mengenal kelompok yang lain dan mengapresiasi perbedaan-perbedaan yang ada. Ide mengintegrasikan etnomatematika ke dalam kurikulum dan pedagogi merefleksikan perkembangan di dalam pendidikan matematika. Istilah pendekatan etnomatematika juga sering digunakan yang merujuk pada kajian etnomatematika. Pendekatan etnomatematika dimaksudkan untuk membuat materi pelajaran matematika sekolah lebih relevan dan berarti bagi siswa serta untuk menyebarluaskan keseluruhan kualitas pendidikan. ${ }^{12}$ Dengan mengimplementasikan pendekatan etnomatematika diharapkan guru dan siswa mendapatkan ide tentang etnomatematika dan akhirnya dapat meningkatkan prestasi belajar matematika.

Lebih jauh, terdapat lima kemungkinan kurikulum etnomatematika dapat diterapkan; yaitu (1) etnomatematika harus dirancang dalam konteks yang sesuai dan 
berarti, (2) disampaikan dalam bentuk conten atau isi budaya khusus yang berbeda dengan konsep matematika umumnya, (3) Konsep berikutnya dalam kurikulum etnomatematika adalah membangun ide bahwa etnomatematika berada pada tahapan pengembangan pemikiran matematika yang terapkan dalam bidang pendidikan, (4) penerapan kurikulum etnomatematika dapat menjadi bagian ide matematika, (5) Kurikulum etnomatematika merupakan integrasi konsep dan praktek matematika ke dalam budaya siswa. ${ }^{13}$ Tujuan mengembangkan model kurikulum etnomatematika adalah untuk membantu siswa menjadi sadar akan bagaimana siswa dapat berpikir secara matematik menurut budaya dan tradisi mereka. Di samping itu, guru diharapkan dapat membantu si swa meningkatkan kemampuan berhitung dan berpikir secara matematika dalam berbagai konteks.

\section{METODE}

Jenis penelitian ini merupakan penelitian kualitatif. Penelitian ini dilakukan pada Sekolah Dasar Negeri Watumerembe dipilih 2 orang guru, sebab guru kelas VI merangkap tugas di kelas $\mathrm{V}$, guru kelas yang biasanya membawakan materi matematika yang bertugas di kelas $V$ telah memasuki masa persiapan pensiun. Satu orang guru dari kelas IV, satu orang guru yang merangkap tugas di kelas V dan VI. Tiga orang siswa dari masing-masing kelas dipilih sebagai data pendukung. Penelitian ini menggunakan pendekatan fenomenologis yang bertujuan untuk mendapatkan informasi selengkap mungkin mengenai implementasi etnomatematika dalam pembelajaran matematika pada tingkat sekolah dasar. Metode pengumpulan data menggunakan teknik observasi, wawancara, dan dokumentasi, kemudian dianalisis berdasarkan analisis logis. Teknik analisis data menggunakan pola analisis Miles dan Huberman yang merujuk pada tiga alur kegiatan secara bersamaan, yaitu reduksi data, sajian data, verifikasi, dan penyimpulan. Tahap-tahap pengumpulan data dalam penelitian ini, yaitu tahap orientasi, tahap eksplorasi, dan tahap member chek.

\section{HASIL PENELITIAN}

\section{Implementasi Etnomatematika di Sekolah Dasar}

\section{Pembelajaran}

\section{a. Rencana pembelajaran}

Rencana pembelajaran yang digunakan dalam penelitian ini ada dua macam, yaitu rencana pembelajaran yang dibuat oleh penulis dan rencana pembelajaran yang dibuat oleh guru. Rencana pembelajaran yang penulis susun bertujuan agar dapat dimanfaatkan sebagai sarana dalam menggali etnomatematika yang dimiliki oleh siswa, dan sebagai model persiapan pembelajaran yang dibuat oleh guru. Persiapan pembelajaran memuat: tujuan, uraian kegiatan pembelajaran, evaluasi dan dilengkapi petunjuk guru yang penulis susun sebagai berikut: 
Rencana pembelajaran yang disusun oleh guru kelas IV, V, VI mengacu pada kurikulum dan buku paket yang direkomendasikan oleh Cabang Diknas Kabupaten Konawe Selatan. Berdasarkan hasil analisis data menunjukkan bahwa penyusunan rencana pembelajaran yang berlaku untuk semua bidang studi, mengacu pada rencana pembelajaran yang diedarkan oleh pihak cabang Diknas Kabupaten Konawe Selatan. Begitupun dengan pengadaan sejumlah buku paket bagi setiap sekolah, sehingga guru yang mengajar menggunakan rencana pembelajaran yang telah disediakan oleh pihak Diknas terkait. Menurut mereka (guru) terkadang mereka tidak konsisten dalam merencanakan dan melaksanakan rencana pembelajaran tersebut, hal ini disebabkan oleh beberapa hal:

1. Beban tugas guru terasa sangat berat, sebab mereka lebih banyak merangkap mengajar beberapa bidang studi di beberapa kelas.

2. Sarana dan prasarana sebagai pendukung utama kegiatan pembelajaran sangat terbatas, dengan sendirinya menuntut mereka bekerja keras.

3. Para guru tidak terbiasa menuliskan gagasan termasuk rencana pembelajaran dalam bentuk tertulis.

4. Para guru memiliki keyakinan berdasarkan pengalaman mengajar selama bertahun-tahun, tanpa menyusun rencana pembelajaranpun mereka tetap mampu meluluskan siswanya.

Terkait dengan ungkapan di atas, hal ini akan mempunyai pengaruh positif dalam membelajarkan siswa. Keyakinan ini akan mempengaruhi cara mereka mengajar. Para guru yang telah berpengalaman dalam pembelajaran matematika, tentu telah memiliki cara dan strategi tertentu yang tepat untuk memecahkan soal matematika tertentu.

Pemaparan rencana pembelajaran yang disusun oleh guru kelas IV tidak jauh berbeda dengan yang penulis susun. Perbedaan hanya terlihat pada strategi mengajar. Penulis menggunakan permainan siswa sebagai bahagian dalam pembelajaran yang berlangsung di sela-sela permainan siswa sehingga suasana belajar matematika tercipta dalam permainan siswa tersebut. Strategi mengajar yang sama, penulis terapkan pada siswa kelas V dan VI. Penulis melihat antusiasme siswa dalam belajar matematika dengan memotivasi mereka, bahwa untuk setiap jawaban benar yang mereka hasilkan akan memperoleh pengembalian sebutir kelereng yang disimpan oleh guru, aturan yang sama berlaku untuk setiap latihan soal yang diberikan.

Berdasarkan penjelasan dari para guru, rencana pembelajaran yang mereka susun mengacu pada kurikulum dan buku paket yang diedarkan oleh Diknas Kabupaten Konawe Selatan. Persiapan mengajar yang disusun berrdasarkan acuan yang ditetapkan oleh Diknas setempat. Walaupun demikian pelaksanaan pola konstruktivis yang diharapkan telah nampak.

Rencana pembelajaran yang disusun oleh guru kelas V dan VI berbeda dengan rencana pembelajaran yang penulis susun, demikian pula pada strategi mengajar yang diterapkan. Sebelumnya penulis telah ungkapkan bahwa guru kelas yang mengajar di kedua kelas tersebut sama, sebab guru yang bertugas di kelas $\mathrm{V}$ telah mema- 
suki masa pensiun. Rencana pembelajaran guru kelas V dan VI, dibuat dengan mengacu pada panduan RPP yang diedarkan oleh cabang Diknas Kabupaten Konawe Selatan. Pendekatan etnomatematika sudah mulai diterapkan diterapkan, walaupun dalam penyusunan RPP tidak nampak, tetapi selama proses pembelajaran matematika berlangsung terkadang digunakan, terutama pada saat mengajarkan materi bangun datar. Bahasa pengantar yang digunakan selama proses pembelajaran adalah bahasa Tolaki, hal ini dilakukan agar lebih memudahkan siswa memahami materi yang diajarkan. Selain itu kegiatan pembelajaran lebih didominasi oleh guru, hal serupa juga terjadi di kelas IV.

Rumusan tujuan pembelajaran khusus mengacu pada edaran resmi yang berlaku untuk semua sekolah yang berada di bawah naungan Kantor Cabang Diknas Konawe Selatan, sehingga semua kriteria lengkap yang memuat unsur-unsur TPK seperti A (Audience), B (Behavior), C (Condition), dan D (Degree) walaupun dalam prakteknya terkadang mereka tidak konsisten dengan edaran tersebut dikarenakan oleh beberapa faktor seperti: beban tugas guru sangat berat, karena seorang guru harus mengajar rangkap di beberapa kelas dengan beberapa bidang studi serta sarana dan prasarana sebagai pendukung utama kegiatan pembelajaran sangat terbatas, dengan sendirinya menuntut mereka bekerja keras.

Dari hasil pengamatan menunjukkan bahwa guru telah mampu menggali konsepsi awal siswa dengan baik dengan materi yang disajikan. Mereka termotivasi untuk menggunakan pendekatan etnomatematika dalam setiap pembelajaran khususnya bidang studi matematika. Penggalian konsepsi awal siswa melalui pertanyaan dengan dialog dan didukung oleh alat peraga sederhana yang dekat dengan keseharian siswa dapat memberikan arti tersendiri dalam suasana belajar yang berbeda dari biasanya. $G_{1}$ (guru 1) menggunakan pola permainan siswa dalam pembelajaran begitupun halnya $\mathrm{G}_{2}$ (guru 2), sebab kebersamaan siswa terutama pada saat istirahat sekolah, terlihat setiap siswa membaur dengan siswa dari kelas berbeda dalam beraktivitas (bermain) dan penulis tidak menemukan mereka berada dalam kelompokkelompok homogen (sekelas, sejenis, seusia) seperti yang sering kita temukan di beberapa sekolah di perkotaan. Penggunaan alat peraga yang dekat dengan keseharian siswa sangat diperlukan, karena pemahaman siswa akan lebih bertahan lama.

Pada pelaksanaan pembelajaran baik $\mathrm{G}_{1}$ maupun $\mathrm{G}_{2}$ telah melaksanakan langkah-langkah yang jelas pada kegiatan pembelajaran seperti (a) tingkat kongkret, dimana siswa memanipulasi benda-benda kongkret seperti bentuk-bentuk bangun datar yang ada pada pola permainan tradisional maupun pada benda-benda dari budaya mereka (motif o'tenda, bentuk kalo, o'boru, dan motif tenunan sarung), (b) tingkat menggambar, disini siswa menggunakan gambar dalam memahami konsep berbagai bangun geometri yang terdapat pada pola permainan mereka, (c) tingkat symbol, pada tingkatan ini siswa menggunakan symbol berupa lambang bilangan dalam menentukan banyaknya persegi yang terdapat dalam setiap permainan.

Selain itu baik $G_{1}$ maupun $G_{2}$ sudah mulai mengarahkan siswa untuk memahami konsep yang sesungguhnya dengan menganjurkan siswa untuk mengamati seti- 
ap pola permainan tradisional dan beberapa motif benda-benda yang lekat dengan keseharian siswa.

b. Pelaksanaan pembelajaran

Pembelajaran diawali dengan menjejaki pemahaman awal siswa yang berkaitan dengan kegiatan bermain mereka (etnomatematika). Pada penjajakan ini penulis menggunakan media permainan siswa dan gambar o'tenda sebagai alat peraga dalam pembelajaran matematika, terutama pada pokok bahasan geometri (bangun datar, garis lurus, simetri, dan jual beli). Kesemua topic ini dapat dikaitkan langsung dengan aktivitas siswa diluar jam sekolah, seperti yang terdapat pada pola permainan tradisional tersebut.

Pelaksanaan kegiatan pembelajaran disesuaikan dengan situasi setempat dan selalu mengaitkan etnomatematika pada topic-topik yang relevan. Pembelajaran juga dilakukan guna mengisi kekosongan kelas, karena keterbatasan tenaga pengajar khususnya pada bidang studi matematika untuk kelas V, dan VI. Seorang guru mengajar pada dua kelas atau lebih untuk beberapa bidang studi, sehingga untuk menunggu giliran pembelajaran berikutnya terjadi kekosongan di beberapa kelas karena kekurangan guru.

Pada jam istirahat sekolah, penulis banyak terlibat dialog dalam menyisipkan sejumlah materi pembelajaran yang mereka telah pelajari di semester ganjil seperti yang penulis jabarkan pada halaman 89, yang terkait dengan jenis permainan yang dilakukan dan menjelaskan nilai matematika yang terdapat pada permainan siswa. Permainan baguli merupakan permainan faforit siswa, dan penulis berkesempatan menyisipkan nilai matematika yang terdapat pada permainan baguli. Momen ini disambut dengan antusias siswa, karena sebelumnya permainan ini dilarang dilakukan di lingkungan sekolah. Pembelajaran matematika untuk ke empat pokok bahasan seperti yang penulis telah paparkan pada halaman 89, dapat berlangsung dengan lancer tanpa mengganggu aktivitas bermain siswa. Pembelajaran seperti ini merupakan salah satu strategi penulis dalam menumbuhkan minat siswa akan pembelajaran matematika yang berkesan. Pembelajaran untuk materi tersebut di atas, tidak penulis lakukan dalam kelas, mengingat materi ini sifatnya pengulangan dan penyegaran kembali bagi siswa, sebab materi tersebut telah dipelajari pada semester ganjil.

Pada tanggal 16 Februari 2009, penulis melakukan pembelajaran di kelas IV SDN Watumerembe. Berikut cuplikan dialog bersama siswa kelas IV SDN Watumerembe, dengan menggunakan kode $\mathrm{P}$ (penulis) sebagai guru dan $\mathrm{S}$ (siswa).

P: Assalamu Alaikum Warahmatullahi Wabarakatuh.

S: Waalaikum Salam Warahmatullahi Wabarakatuh.

P: Selamat pagi anak-anak.

S: Selamat pagi, bu!

P: Apakah kalian telah siap mengikuti pelajaran pagi ini?

S: Sudah, bu!

P: Saya sering melihat kalian bermain dende yang bentuknya seperti ini (penulis menggambarkan pola permainan di atas papan tulis). 
S: Oh...itu permainan lamari, bu!

P: Oh ya, kalau begitu ada permainan lain yang kalian sering mainkan selain ini?

S: Ada, bu!

P: Kalau begitu coba kalian sebutkan dan gambar di papan tulis. (penulis menunjuk salah seorang siswa secara bergiliran untuk menggambar pola permainan tersebut).

P: Sekarang coba amati gambar permainan yang baru saja kalian buat, bentuk bangun apa saja yang kalian dapat temukan dari permainan tersebut! (penulis menunjuk salah seorang siswa bergiliran untuk menggambarkan bangun geometri tersebut).

S: Bentuk segi empat, segi tiga, lingkaran, bu!

P: Adakah bentuk persegi panjang pada gambar ini? (penulis menunjuk gambar permainan robot).

S: Iya, bu! ada empat persegi panjang.

P: Betul! Nah sekarang buka buku pelajaran kalian, carilah rumus yang sesuai dengan bentuk bangun datar yang kalian gambarkan, lalu perlihatkan kepada ibu.

S: Sudah selesai, bu! ini gambar dan rumusnya.

P: Bagus sekali. Terima kasih. (penulis mengembalikan beberapa butir kelereng sebagai bentuk penghargaan dari jawaban benar yang mereka lakukan).

Penulis menyaksikan awal pelajaran dimulai, siswa terlihat segan dan kaku dalam mengikuti pelajaran, setelah penulis meminta mereka menggambarkan pola permainan, suasana belajar menjadi lebih santai dan siswa terlihat aktif mengikuti pelajaran.

Ketika penulis melaksanakan pembelajaran di kelas V SDN Watumerembe dengan pokok bahasan geometri dan pengkuran. Sebelum masuk ke kelas, penulis sempat melihat beberapa siswa perempuan bermain disco di halaman sekolah. Kegiatan belajar mengajar dimulai pukul 07.30, tetapi beberapa siswa sudah terlihat hadir di sekolah lebih awal karena diantara mereka ada yang bertugas membersihkan kelas, ada juga siswa yang menjajakan kue dan es manis, serta ada juga siswa yang bermain. Salah seorang siswa (Rani duduk di kelas V) datang ke sekolah sambil berjualan kue. Beberapa pertanyaan yang penulis ajukan padanya: Setiap hari Rani berjualan ubi goreng sebanyak 12 potong dan tumbuh (sejenis gogos/nasi ketan) sebanyak 16 potong dengan harga Rp. 500/potong (harga tersebut berlaku untuk semua jenis jualan Rani). Berapa rupiah yang diperoleh jika ubi goreng Rani habis terjual? Rani terlihat menghitung jumlah ubinya, lalu dengan spontan menjawab Rp. 6.000,00 bu. Selanjutnya penulis menanyakan hal yang sama pada Rani untuk jajanan tumbu, dan Rani melakukan teknik yang sama untuk jajanan tumbu, bahwa dia akan memperoleh uang Rp. 8.000,00 jika semua jajanan tumbu laku terjual. Selanjutnya penulis menanyakan berapa total uang yang akan diperoleh jika semua dagangannya habis terjual. Rani terlihat gugup dan lama berfikir (karena pagi itu seluruh dagangan Rani masih utuh), beberapa temannya langsung menjawab pertanyaan penulis dengan benar, Rp. 14.000,00. Penulis menanyakan kepada rekan Rani, bernama Krismon (duduk di kelas 
VI) yang membantu memberikan jawaban tersebut. Krismon menjawab bahwa jumlahnya Rp. 14.000,00 yang diperoleh dari penjumlahan total harga ubi goreng Rp. 6.000,00+total harga tumbu Rp. 8.000,00 (saat penjumlahan ini penulis tanyakan pada Rani, terdapat 3 orang siswa yang menjawab spontan dengan benar).

Berikut cuplikan dialog penulis $(\mathrm{P})$ dengan siswa kelas V SDN Watumerembe.

P: Assalamu Alaikum Warahmatullahi Wabarakatuh.

S: Waalaikum Salam Warahmatullahi Wabarakatuh.

P: Selamat pagi anak-anak.

S: Selamat pagi, bu!

P: Hari ini ibu membawa beberapa gambar. (penulis memperlihatkan foto o'tenda). Gambar apa ini?

S: Saya, bu! (terlihat siswa serempak menjawab). Itu gambar tenda.

P: Betul sekali. Apakah ada seperti ini di rumah?

S: Ada, bu! (siswa yang memiliki o'tenda di rumah menjawab).

P: Coba kalian amati, bentuk bangun apa saja yang terdapat pada gambar o'tenda ini?

S: Gambar segitiga, bu! (siswa serempak menjawab).

P: Perhatikan baik-baik gambar ini! (penulis membantu siswa mengamati gambar o'tenda dengan menunjuk garis-garis berwarna yang membatasi beberapa pola segitiga). Bagaimana dengan bahagian tengah o'tenda ini?

S: Oh...bentuk persegi panjang dan segitiga sama sisi, bu!

P: Jawaban yang bagus.

Dari dialog di atas terlihat bahwa penggunaan gambar o'tenda dapat dijadikan salah satu alat peraga yang sangat dekat dengan keberadaan siswa setempat disamping penggunaan beberapa pola permainan mereka. Selain itu aktivitas jual beli yang dilakukan oleh beberapa orang siswa di luar jam belajar sekolah (etnomatematika), dapat dijadikan sebagai bagian dari pembelajaran matematika praktis yang sering dijumpai diluar jam belajar.

Pada hari yang sama, penulis mengunjungi salah seorang siswa bernama Afdal (IV) yang biasanya menggantikan tugas orang tuanya berjualan bensin di depan rumah sepulang dari sekolah. Harga bensin sebotol dijual Rp. 6.000,00/botol. Saat itu ada seorang pengendara motor yang mampir untuk mengisi bensin sebanyak 2 botol, dan pembeli tersebut menyodorkan uang sebanyak Rp. 20.000,00, dengan sigap Afdal mengembalikan uang pembeli tersebut sebanyak Rp. 8.000,00. Setelah pembeli tersebut berlalu, penulis mewawancarai Afdal seputar aktivitasnya tersebut, berikut cuplikan wawancara penulis (P) dengan Afdal (A).

P: Sudah berapa lama Afdal membantu orang tua jualan bensin?

A: Sudah lama bu, saya tidak ingat lagi, kayaknya sejak saya kelas III SD.

P: Bensinnya boleh dibeli $1 / 2$ botol? (penulis mencoba cara lain untuk menggali kemampuan Afdal dalam jual beli).

A: Boleh, pernah ada yang beli cuma $1 / 2$ botol.

P: Berapa harga bensinnya kalau Cuma $1 / 2$ botol? 
A: Rp. 3.000,00 bu.

P: Kalau ibu beli $1 / 2$ botol dengan uang Rp. 20.000,00 berapa kembalian uang ibu? (Afdal terlihat sebentar berfikir sebelum menjawab)

A: Rp. 17.000,00 bu.

P: Betul sekali, semoga usaha bensinnya laris. Terima kasih atas kesediaannya meluangkan waktu, sampai jumpa di sekolah besok.

A: Sama-sama, bu!

Dari cuplikan percakapan di atas, terlihat bahwa siswa telah memiliki pengetahuan awal seputar operasi hitung (penjumlahan dan pengurangan) yang mereka miliki di luar aktivitas belajar, selain aktivitas permainan tradisional dan hal semacam inilah yang perlu digunakan seorang guru dalam melaksnakan proses pembelajaran formal di kelas.

Berdasarkan hasil pengamatan penulis bahwa penggunaan permainan tradisional, aktivitas jual beli yang dilakukan beberapa siswa, dan penggunaan $o^{\prime}$ tenda merupakan cara praktis dalam membangkitkan motivasi belajar siswa khususnya pada bidang studi matematika karena pembelajaran banyak melibatkan aktivitas keseharian siswa.

Pelaksanaan pembelajaran yang dilakukan oleh guru kelas-kelas tinggi telah mampu menciptakan suasana pembelajaran yang sesuai dengan konsep yang diajarkan dengan menggunakan alat peraga yang lekat dengan keseharian siswa hanya saja tidak tampak pada rencana pembelajaran yang disusun. Pemahaman konsep beberapa bangun geometri disajikan dengan menggunakan pola permainan tradisional yang lekat dengan keseharian siswa, sehingga siswa akan lebih aktif dan bersemangat mengikuti pelajaran. Selain itu guru kelas-kelas tinggi tersebut menyebutkan dalam bahasa daerah setempat nama-nama bangun geometri tersebut dalam bahasa daerah Tolaki guna mempermudah pemahaman siswa dalam proses pembelajaran.

Pelaksanaan lokakarya mini yang penulis lakukan dengan pihak sekolah, merupakan perwujudan implementasi etnomatematika di Sekolah Dasar. Pihak sekolah mendukung sosialisasi pendekatan etnomatematika dalam rangka mengisi muatan lokal yang menjadi bahagian dari kurikulum. Hal ini terlihat dari keseriusan mereka dalam belajar bersama, sehingga menghasilkan kerja yang sesuai dengan apa yang telah direncanakan. Pihak sekolah juga merasa berkepentingan untuk memanfaatkan dan mengembangkan etnomatematika yang berlatar budaya setempat.

Sebelum lokakarya tersebut dilaksanakan, penulis menyebarkan angket kepada para guru terlihat bahwa jenjang pendidikan guru kelas $\mathrm{V}$ (guru honor) adalah sarjana dan guru kelas V dan VI tamatan SPG, juga ditemukan bahwa sebahagian guru pernah menerapkan pendekatan etnomatematika ini kepada siswa mereka, ketika itu salah seorang guru berusaha menjelaskan kepada siswa dengan mengingatkan salah satu permainan yang sering mereka lakukan, tetapi guru tersebut tidak menyadari bahwa secara tidak langsung dia telah menerapkan pendekatan etnomatematika. Melalui lokakarya mini, mereka memperoleh informasi tentang etnomatematika. 
Berdasarkan pengamatan terhadap situasi sekolah dan wawancara dengan Kepala Sekolah SDN Watumerembe, terdapat kendala dalam pengelolaan sekolah, antara lain:

1. Beban tugas guru sangat berat, karena seorang guru harus mengajar rangkap di beberapa kelas dengan beberapa bidang studi. Hal ini akibat tenaga pengajar yang tersedia serba terbatas, sehingga terkadang kelas-kelas rendah yang seharusnya pulang lebih awal (jam 10.00) kenyataannya harus pulang jam 12.00 atau lebih. Kepala sekolah juga mengajar di beberapa kelas, selain menangani administrasi sekolah, sehingga jika ada urusan dinas luar dengan sendirinya tugas mengajar akan dialihkan ke guru lainnya.

2. Sarana dan prasarana yang tersedia sangat terbatas. Sarana ini meliputi buku paket, alat peraga, perpustakaan, alat olahraga dan beberapa penunjang lainnya.

Penulis mengusulkan jika pembelajaran matematika formal menggunakan pendekatan etnomatematika, akan lebih baik apabila guru yang mengajar pada kelaskelas tinggi berasal dari daerah setempat atau guru yang telah berpengalaman. Pengaruh seorang guru turut andil dalam membentuk pola pikir dan sikap seseorang.

Kondisi sekolah tempat penelitian cukup memprihatinkan, karena terdapat kendala-kendala dan keterbatasan dalam pelaksanaan. Namun demikian pihak sekolah berkeinginan untuk meningkatkan mutu pendidikan dan pengajaran. Salah satu cara yang dilakukan adalah dengan menggunakan materi muatan local untuk memperkaya pemahaman siswa khususnya bidang studi matematika. Hal ini dapat memberi kemudahan bagi siswa, oleh sebab itu diperlukan guru yang telah berpengalaman atau guru yang berasal dari masyarakat setempat. Dikuatirkan guru yang datang dari luar daerah atau belum berpengalaman akan mengalami benturan-benturan karena lintas budaya. Seperti yang dikemukakan oleh Bishop (1994:16) mengungkapkan bahwa benturan muncul bervariasi dan dan menyangkut semua atau sebahagian faktor berikut: bahasa, konsep geometri, alasan logis, nilai-nilai dan kepercayaan, prosedur perhitungan, representasi symbol/lambang, sikap, tujuan preferensi (pilihan) kognitif. Selanjutnya beliau menyatakan bahwa guru matematika sebagai antropologi sosial yang harus memahami pengetahuan matematika di luar sekolah.

Penulis melihat bahwa etnomatematika memiliki peluang untuk dikembangkan dan diterapkan di daerah Sulawesi Tenggara, tentunya disesuaikan dengan tujuan kurikulum dimana sekolah harus mengembangkan muatan local. Etnomatematika merupakan alternative untuk menerapkan kurikulum muatan local. Dasar pelaksanaan kurikulum muatan local adalah Undang-undang No. 20 Tahun 2003 pasal 37 ayat 1 menyatakan bahwa "kurikulum Pendidikan Dasar dan Menengah wajib memuat: J. muatan lokal". Ketentuan ini pada jenjang satuan pendidikan dasar dapat menjabarkan dan menambah bahan kajian dari mata pelajaran sesuai dengan kebutuhan setempat. Keputusan Direktur Jenderal Pendidikan Dasar dan Menengah No. 173/C/ Kep/M/1987 menyatakan bahwa yang dimaksud dengan muatan local ialah suatu program pendidikan yang isi dan media penyampaiannya dikaitkan dengan lingkungan alam, lingkungan social, lingkungan budaya, dan pola kehidupan, serta kebutuhan pembangunan yang wajib dipelajari murid di daerah tersebut sehingga me- 
mungkinkan seorang guru dalam melaksnakan pembelajaran matematika di kelas mampu mengaitkan antara matematika di sekolah dengan matematika di luar sekolah.

\section{SIMPULAN}

Pada proses pembelajaran matematika guru kelas IV telah memanfaatkan etnomatematika, hal ini terlihat dari penyusunan renacana pembelajaran maupun saat menyampaikan materi pelajaran, walaupun masih terbatas, begitu pula halnya guru yang merangkap tugas di kelas V dan kelas VI telah memanfaatkan etnomatematika dalam pembelajaran matematika, walaupun dalam menyusun rencana pembelajaran sama sekali tidak terlihat etnomatematika termuat di rencana pembelajaran yang dibuat. Hal ini disebabkan ketersediaan rencana pembelajaran yang diedarkan oleh pihak Cabang Diknas Pemda Konawe Selatan.

Penerapan etnomatematika sebagai sarana untuk memotivasi, menstimulasi siswa, dapat mengatasi kejenuhan dan kesulitan dalam belajar matematika. Hal ini disebabkan etnomatematika merupakan bahagian dari keseharian siswa yang merupakan konsepsi awal yang telah dimiliki dari lingkungan social budaya setempat. Selain itu etnomatematika memberikan nuansa baru pada pembelajaran matematika.

Nilai matematika yang terdapat pada permainan lamari, disko, dan permainan robot adalah kelipatan dan factor bilangan, hal ini terlihat pada aturan jumlah pemain yang selalu berpasangan dimulai dari 2, 4, dan 6 yang merupakan urutan bilangan kelipatan 2, sedangkan pada permainan baguli materi pembelajaran matematika yang dapat dipeoleh dari permainan ini terdiri atas:

1. Membandingkan dan mengurutkan bilangan bulat

2. Melakukan operasi penjumlahan dan perkalian bilangan bulat.

3. Melakukan pengenalan bilangan asli

4. Melakukan pengukuran dengan menggunakan konsep keliling dan luas.

Siswa SDN Watumerembe secara umum telah memiliki pengetahuan awal seputar enam aktivitas lingkungan yang bernuansa matematika. Hal ini dapat terlihat dari hasil dialog dan wawancara penulis dengan siswa selama proses pembelajaran di kelas maupun di luar jam belajar.

\section{CATATAN AKHIR}

1. Kennedy dan Tipps, Rediesel, dalam Tandililing, dkk., Pengembangan Etnomatematika dalam Suku Dayak Kanayat'n di Kalimantan Barat (Suatu Upaya Pengembangan Bahan Ajar Matematika di Sekolah Dasar). Laporan Hasil Penelitian. FKIP Universitas Tanjungpura. Pontianak. Tidak diterbitkan. 2006:12.

2. Strigler, dkk dalam Silvia, Pengembangan Bahan Ajar Matematika yang Bernuansa Etnomatematika dalam Suku Dayak Kanayat'n di Kalimantan Barat untuk membantu Siswa Sekolah Dasar Mempelajari Konsep Matematika. Penelitian Fundamental, Tidak diterbitkan, 1999:9.

3. Muhammad Yaumi, Yaumi, Muhammad. Pengertian Konstruktivisme. Artikel Online (http://teoribelajar.blogspot.com/2008/10/pengertian-konstruktivisme.html) Diakses pada tanggal 15 November 2008. 
4. Munaldus, 1998, Etanomatematika Dalam Masyarakat Dayak di Kalimantan Barat. Pontianak: FMIPA-FKIP UNTAN.

5. D'Ambrosio, U. (2003). Stakes in Mathematics Education for the Societies of Today and Tomorrow. One Hundred Years of L'Enseignement Mathématique, Moments of Mathematics Education in the Twentieth Century. Proceedings of the EM-ICMI Symposium, Geneva, p. 20-22, in Daniel Coray et al (Eds). L'Enseignement Mathématiques, Genève, 302-316.

6. Adam, S. (2004). "Ethnomatematical Ideas in the Curriculum". Mathematics Education Journal, 2004. Vol. 16, No. 2, hal. 49-68.

7. Shirley, L. (2008). Looks Back Ethnomathematics and Look Forward. Jurnal International Congress of Mathematics Education (6-13 Juli 2008). Atikel Online (http://pages.towson.edu/shirley/ethnomath\%20looks\%20back\%20forward.htm) Diakses pada tanggal 20 Agustus 2008.

8. Bishop, J. A. (1988). Mathematics education in its cultural context. Educational Studies in Mathematics, 19, 179-191.

9. Sayu, Silvia, dkk. (2008). Pengembangan Bahan Ajar Matematika yang Bernuansa Etnomatematika dalam Suku Dayak Kanayat'n di Kalimantan Barat untuk membantu Siswa Sekolah Dasar Mempelajari Konsep Matematika. Penelitian Fundamental Tahun anggaran 2009. Tidak diterbitkan.

10. Muhammad Yaumi, op.cit. hal. 1-2.

11. H.A.R. Tilaar, Multikulturalisme Tantangan-tantangan Global Masa Depan dalam Transformsi Pendidikan Nasional, Jakarta: Grasindo, 2004.

12. Adam, S., "Ethnomatematical Ideas in the Curriculum". Mathematics Education Journal, 2004. Vol. 16, No. 2, hal. 49-68.

13. Adam, S., Alangui, W., \& Barton, B. (2003). A comment on Rowlands and Carson 'Where would formal academic mathematics stand in a curriculum informed by ethnomathematics? A critical review'. Educational Studies in Mathematics, 52(3), 327-335.

\section{DAFTAR PUSTAKA:}

Adam, S. (2004). "Ethnomatematical Ideas in the Curriculum". Mathematics Education Journal, 2004. Vol. 16, No. 2, hal. 49-68.

Adam, S., Alangui, W., \& Barton, B. (2003). A comment on Rowlands and Carson 'Where would formal academic mathematics stand in a curriculum informed by ethnomathematics? A critical review'. Educational Studies in Mathematics, 52(3), 327-335.

Bishop, J. A. (1988). Mathematics education in its cultural context. Educational Studies in Mathematics, 19, 179-191.

D'Ambrosio, U. (2003). Stakes in Mathematics Education for the Societies of Today and Tomorrow. One Hundred Years of L'Enseignement Mathématique, Moments of Mathematics Education in the Twentieth Century. Proceedings of the EM-ICMI Symposium, Geneva, p. 20-22, in Daniel Coray et al (Eds). L'Enseignement Mathématiques, Genève, 302-316.

Kennedy dan Tipps, Rediesel, dalam Tandililing, dkk., Pengembangan Etnomatematika dalam Suku Dayak Kanayat'n di Kalimantan Barat (Suatu Upaya Pengembangan Bahan Ajar Matematika di Sekolah Dasar). Laporan Hasil Penelitian. FKIP Universitas Tanjungpura. Pontianak. Tidak diterbitkan. 2006:12.

Munaldus, (1998). Etanomatematika Dalam Masyarakat Dayak di Kalimantan Barat. Pontianak: FMIPA-FKIP UNTAN.

Sayu, Silvia, dkk. (2008). Pengembangan Bahan Ajar Matematika yang Bernuansa Etnomatematika dalam Suku Dayak Kanayat'n di Kalimantan Barat untuk membantu Siswa Sekolah Dasar Mempelajari Konsep Matematika. Penelitian Fundamental Tahun anggaran 2009. Tidak diterbitkan. 
Shirley, L. (2008). Looks Back Ethnomathematics and Look Forward. Jurnal International Congress of Mathematics Education (6-13 Juli 2008). Atikel Online (http://pages.towson.edu/shirley/ethnomath\%20looks\%20back\%20forward.htm) Diakses pada tanggal 20 Agustus 2008.

Tilaar, H.A.R., Multikulturalisme Tantangan-tantangan Global Masa Depan dalam Transformasi Pendidikan Nasional, Jakarta: Grasindo, 2004.

Yaumi, Muhammad. (2008). Pengertian Konstruktivisme. Artikel Online (http://teoribelajar.blogspot.com/2008/10/pengertian-konstruktivisme.html) Diakses pada tanggal 15 November 2008. 